\title{
BIMBINGAN KELOMPOK MODEL PERMAINAN UNTUK MENINGKATKAN KREATIFITAS ANAK
}

\author{
Dinar Mahdalena Leksana a,1 \\ ${ }^{a}$ Universitas Islam Lamongan Indonesia \\ ${ }^{1}$ chealeksa.ca@gmail.com
}

\begin{tabular}{l}
\hline Informasi artikel \\
\hline Received : \\
Agust 15, 2018. \\
Revised : \\
Agust 27, 2018. \\
Publish : \\
September 09, 2018. \\
Kata kunci: \\
Bimbingan kelompok; \\
Kemampuan \\
penyesuaian diri di \\
sekolah;
\end{tabular}

Keywords:

Group guidance;

The ability of self adjustment at school;

\begin{abstract}
ABSTRAK
Tujuan dari penelitian ini adalah untuk menguji efektivitas penggunaan layanan bimbingan kelompok dengan belajar untuk berperilaku permainan untuk meningkatkan kreativitas anak-anak. Penelitian ini dilakukan dengan pre-test post-test one group design. Subjek penelitian ini adalah 14 anak TK A Ma'arif Payaman. Teknik analisis data yang digunakan dalam penelitian ini adalah uji peringkat bertanda Wilcoxon. Ditemukan bahwa ada perbedaan yang signifikan antara kemampuan penyesuaian diri pada skor sekolah sebelum dan sesudah perawatan. Berdasarkan uji Wilcoxon ditemukan bahwa $\mathrm{T}$ hitung $=0, \mathrm{~N}=14$ dengan tingkat signifikan 0,01 sehingga $\mathrm{T}$ tabel $=0,05$. Ini berarti $\mathrm{T}$ hitung $<\mathrm{T}$ tabel $(0<0,05)$. Jadi hipotesis penelitian ini diterima. Dapat disimpulkan bahwa layanan bimbingan kelompok dengan belajar berperilaku permainan adalah pendekatan yang efektif untuk meningkatkan aktivitas anak-anak.
\end{abstract}

This work is licensed under a Creative Commons Attribution-ShareAlike 4.0 International License. Allows readers to read, download, copy, distribute, print, search, or link to the full texts of its articles and allow readers to use them for any other lawful purpose. 


\section{PENDAHULUAN}

Pendidikan sebagai usaha sadar untuk pengembangan kepribadian yang belangsung seumur hidup. Pendidikan juga bermakna proses membantu individu baik jasmani dan rohani ke arah terbentuknya kepribadian yang optimal dari setiap peserta didik sesuai dengan potensi dan karakteristiknya masing-masing, dimana peserta didik adalah pribadi-pribadi yang unik dengan segala karakteristiknya. Sebagai individu yang dinamis dan berada dalam proses perkembangan, siswa memiliki kebutuhan dan dinamika dalam interaksi dengan lingkungannya.

Hal ini tidak lepas dari hakekat manusia sebagai makhluk sosial bahwasanya setiap individu memerlukan orang lain dalam kehidupannya. Untuk dapat berhubungan dengan orang lain secara baik, individu dituntut mampu beradaptasi (menyesuaikan diri) dengan lingkungannya. Karena setiap individu memiliki kemampuan yang berbeda dan kreatifitas yang berbeda sehingga kemampuan anak dalam memahami pembelajaranpun berbeda (Juntika, 2006:122).

Berkaitan tentang pendidikan anak usi dini dalam mencerdaskan kehidupan bagsa dalam kalimat tersebut, mempunyai arti mem bentuk generasi yang berkualitas pendidikan harus di mulai sejak dini. Dalam UURI no 20 Tahun 2003 tentang Sisdiknas dijelaskan bahwa "pendidik adalah tenaga kependidikan yang berkualitas sebagai guru, dosen, konselor, pamong belajar, widyaswara, tutor, infrastruktur, fasilitator dan sebutan lainnya dengan kekhususannya, serta berpartisipasi dalam penyelenggaraan pendidikan.” Dengan demikian penyelenggaraan pendidikan tidak melulu pengajaran semata, akan tetapi melakukan berbagai upaya dalam mendampingi anak didik agar berhasil dalam menjalani proses belajar mengajar yang salah satunya berupa pelayanan bimbingan dan konseling. 
Bimbingan dan konseling yang diberlakukan pada pendidikan anak usia dini, merujuk pada paparan oleh Asosiasi Bimbingan dan Konseling Indonesia (ABKIN), bahwa kebutuhan akan layanan bimbingan di TK memiliki tujuan dan ekspektasi tersendiri yang berbeda dengan tujuan ekspektasi pada jenjang sekolah dasar dan seklah menengah. Oleh karena itu, agar konselor dapat berperan secara efektif dan produktif untuk mencapai tujuan bimbingan dan konseling di jenjang pendidikan prasekolah ini ABKIN mengusulkan adanya konselor kunjung (roving counselor), yang berfungsi untuk membantu guru mewujudkan tujuan bimbingan dan konseling di TK dan mengatasi perilaku mengganggu (distruptive behavior) sesuai keperluan. Dari sini dapat dipahami pentingnya pelaksanaan bimbingan dan konseling pada jenjang pendidikan prasekolah.

Meskipun keterlaksanaan layanan bimbingan dan konseling masih sangat terbatas, padahal keberadaan bimbingan dan konseling ini sangat membantu tugas perkembangan dan kepribadian anak, dalam hal ini terdapat beberapa kegiatan bimbingan dan konseling yang dapat dilaksanakan di jenjang pendidikan anak usia dini, salahsatunya adalah bimbingan kelompok.

Bimbingan kelompok merupakan suatu pemberian bantuan (bimbingan) yang diberikan kepada peserta didik melalui kegiatan kelompok. Dalam layanan bimbingan kelompok, aktivitas dan dinamika kelompok harus diwujudkan untuk membahas berbagai hal yang berguna bagi pengembangan dan pemecahan masalah siswa yang menjadi peserta layanan (Martini, 2005:46). Senada dengan yang diungkapkan oleh beberapa tokoh bahwa layanan bimbingan kelompok secara umum bertujuan untuk pengembangan kemampuan bersosialisasi, khususnya kemampuan berkomunikasi peserta layanan (siswa). Secara lebih khusus, layanan bimbingan kelompok bertujuan 
untuk mendorong pengembangan perasaan, pikiran, persepsi, wawasan dan sikap kreatif yang menunjang perwujudan tingkah laku yang lebih efektif, yakni peningkatan kemampuan berkomunikasi baik verbal maupun nonverbal para siswa.

Ada beberapa teknik yang dapat diterapkan dalam layanan bimbingan kelompok, salah satunya adalah teknik umum dan permainan kelompok. Permainan dapat dijadikan sebagai salah satu teknik dalam layanan bimbingan kelompok baik sebagai pelengkap teknik-teknik yang lain maupun sebagai suatu teknik tersendiri yang merupakan wahana pemuat materi pembinaan atau materi layanan tertentu.

Dari tekhnik permainan inilah peneliti menyoroti permasalahan yang ada dengan kesesuaian bantuan. Bermain merupakan cara yang paling tepat untuk membantu anak dalam mengembangkan tugas perkembangannya. Seperti yang disampaikan oleh Piaget (1962) bahwa ada sejumlah tipe bermain dengan obyek yang meliputi bermain praktis, bermain simbolik dan permainan dengan peraturanperaturan. Misalnya dalam permainan gambar, bermain praktis, yaitu bentruk bermain dimana anak-anak melakukan berbagai kemungkinan mengeskplorasiobyek yang digunakan. Dalam hal ini seorang anak memiliki kemampuan untuk memainkannya. Bermain simbolik, yaitu dimana anak menggunakan daya imajinbasi dalam mempergunakan benda tersebut. Anak tidak hanya mampu memainkannya tetapi kartu-kartu gambar juga bias dijadikan sebagai pagar-pagar halaman rumah, hiasanhiasan rumah, dan sebagainya. Sedangkan bermain dengan peraturan yaitu dimana anak telah mampu bermain gambar dengan peraturan-peraturan tertentu.

Berkaitan tentang pembelajaran yang di gunakan pada tingkatan TK. Kita pernah menjumpai banyaknya lembaga-lembaga TK yang menerapkan pembelajaran 
dengan cara bermain sambil belajar. Dalam kegiatan bermain sambil belajar di harapkan dapat membuat anak-anak TK merasa senang.

Setelah anak-anak merasa senang, mereka akhirnya dapat mengoptimalkan Kreatifitas-Kreatifitas yang mereka miliki. Pada kegiatan bermain sambil belajar, kegiatan yang di lakukan adalah berfokus kepada beberapa jenis permainan yang akan di gunakan untuk menstimulasi Kreatifitas mereka. Bermain sambil belajar bukan hanya kegiatan bermain semata, namun kegiatan bermain yang di maksud adalah kegiatan bermain yang dapat menstimulasi minat belajar anak untuk mengembangkan Kreatifitas yang mereka miliki. Bermain adalah suatu kegiatan yang sering di lakukan oleh anak, terutama pada anak usia dini (AUD). Bagi mereka kegiatan bermain adalah suatu kegiatan yang menyenangkan, dan kegiatan bermain adalah suatu kegiatan yang dapat memberikan kepuasan bagi diri mereka.

Berdasarkan latar belakang di atas maka peneliti akan melakukan penelitian untuk menguji penggunaan bimbingan kelompok model permainan untuk meningkatkan kreatifitas anak kelompok TK A Darul Ma’arif, Payaman.

\section{Kreatifitas}

Kreatifitas berasal dari kata kreatif. Dalam Kamus Besar Bahasa Indonesia, kreatif berarti memiliki daya cipta, memiliki kemampuan untuk menciptakan. Jadi, Kreatifitas adalah suatu kondisi, sikap atau keadaan yang sangat khusus sifatnya dan hampir tidak mungkin di rumuskan secara tuntas. Kreatifitas dapat di definisikan dalam beraneka ragam pernyataan tergantung siapa dan bagaimana menyorotinya. Istilah Kreatifitas dalam kehidupan sehari-hari selalu di kaitkan dengan prestasi yang istimewa dalam menciptakan sesuatu yang baru. 
Kreatifitas termasuk salah satu aspek yang di kembangkan dalam pendidikan anak usia dini. Kreatifitas merupakan kemampuan atau cara berpikir sesorang untuk menciptakan atau menghasilkan sesuatu yang baru, dan berbeda. Pengertian Kreatifitas ada berbagai macam. Kreatifitas bisa di artikan sebagai suatu proses munculnya suatu produk baru yang tumbuh dari keunikan individu di satu pihak, serta dari kejadian, orang-orang, dan keadaan hidupnya di lain pihak.Kreatifitas di artikan juga sebagai suatu proses yang tercermin dalam kelancaran, kelenturan (flesibilitas) dan originalitas dalam berfikir.

Tidak terelakkan lagi, pada dasarnya setiap orang memiliki bakat dan kreatifitas, walaupun macam dan tingkat Kreatifitas tersebut berbeda. Dari segi pendidikan, Kreatifitas dalam diri anak memang dapat di tingkatkan. Dari pernyataan tersebut, seharusnya pada usia dini, kemampuan-kemampuan tentang Kreatifitas anak sudah harus di pupuk. Bila kemampuan Kreatifitas anak tidak di pupuk, Kreatifitas tersebut tidak akan berkembang dengan baik.

Bila tidak segera mendapatkan tindak lanjut dari Kreatifitas anak, nantinya Kreatifitas-Kreatifitas yang di miliki anak hanya menjadi suatu bakat yang di pendam. Kreatifitas tidak hanya dalam bentuk musik, seni, atau penulisan-penulisan. Kreatifitas dapat berupa ilmu penegtahuan, ilmu kemasyarakatan, dan bidang-bidang yang lainnya. Untuk anak-anak berusia dini, Kreatifitas anak di fokuskan pada proses pembuatan berbagai gagasan. Penerimaan orang dewasa dari banyaknya gagasan di dalam suasana yang tidak evaluatif.

Pada anak usia dini, gagasan-gagasan yang telah mereka miliki dapat di terapkan ke langkah berikutnya melalui evaluasi diri, dan pembuatan berbagai produk. 
Penekanan pembelajaran pada anak usia dini menekankan berbagai kemampuan untuk menghasilkan dan mengevaluasi hipotesis, dan meninjau kembali gagasan mereka yang di dasarkan pada evaluasi. Memiliki anak-anak yang kreatif memang menjadi dambaan setiap orang tua. Dengan adanya Kreatifitas dalam diri anak, di harapkana anak mampu menyelesaikan setiap masalah yang sedang dia hadapi tanpa harus menunggu bantuan dari orang lain.

Dari adanya ketiga penyataan tersebut, dapat di simpulkan bahwa Kreatifitas yang di miliki setiap orang sangatlah berbeda. Kreatifitas pelu di kembangkan dengan latihan-latihan dan tentu dengan pembiasaan-pembiasaan. Kreatifitas yang sudah di miliki, seharusnya bisa di kembangkan selagi anak-anak masih berada dalam masa Golden Age (masa keemasan). Seorang anak, yang sudah mempunyai bakat Kreatifitas tinggi, akan menunjukkan Kreatifitas mereka hanya dengan beberapa kali stimulus oleh guru. Seseorang yang bakat Kreatifitas tinggi ataupun sedang, dapat di stimulus dengan berulang-ulang agar Kreatifitasnya bisa berkembang sesuai harapan.

\section{Bimbingan Kelompok}

Tohirin menyatakan bahwa layanan bimbingan kelompok merupakan suatu cara memberikan bantuan (bimbingan) kepada individu (siswa) melalui kegiatan kelompok. Dalam layanan bimbingan kelompok, aktivitas dan dinamika kelompok harus diwujudkan untuk membahas berbagai hal yang berguna bagi pengembangan atau pemecahan permasalahan individu yang menjadi peserta layanan.

Keunggulan bimbingan kelompok menurut Prayitno dalam Nursalim meliputi: 
a. Menyangkut aspek ekonomis/ efisiensi, yaitu dengan adanya kelompok akan semakin banyak orang yang dibantu sehingga relatif membutuhklan waktu yang lebih cepat

b. Dengan adanya interaksi yang intensif dan dinamis diharapkan tujuan bimbingan dapat tercapai secara lebih mantap

c. Dinamika yang terjadi dalam kelompok mencerminkan suasana kehidupan nyata yang dapat dijumpai di masyarakat

Alasan penggunaan bimbingan kelompok antara lain :

a. Adanya tuntukan kebutuhan seseorang akan suasana kelompok

b. Banyaknya siswa yang mengalami masalah

c. Adanya suatu masalah yang harus dipecahkan melalui kelompok yaitu dengan mesdiskusikannya bersama-sama dalam kelompok

d. Untuk menolong individu agar lebih baik dalam hubungan sosial dan memperbaiki sifat-sifat pribadinya

e. Untuk mengatasi masalah-masalah yang sama sehingga bisa dilakukan bimbingan secara bersama-sama

Secara umum layanan bimbingan kelompok bertujuan untuk pengembangan kemampuan bersosialisasi, khususnya kemampuan berkomunikasi siswa. Secara lebih khusus, layanan bimbingan kelompok bertujuan untuk mendorong pengembangan perasaan, pikiran, persepsi, wawasan dan sikap yang menunjang perwujudan tingkah laku yang lebih efektif, yakni peningkatan kemampuan berkomunikasi baik verbal maupun nonverbal para siswa. 
Menurut Jumhur dan Surya dalam Nursalim teknik-teknik bimbingan meliputi : home room, karya wisata, diskusi kelompok, kegiatan kelompok, remidial teaching, psikodrama, sosiodrama, bermain dan kerja kelompok.

Permainan dapat dijadikan sebagai salah satu teknik dalam layanan bimbingan kelompok baik sebagai selingan maupun sebagai wahana yang memuat materi pembinaan atau materi layanan tertentu.

Permainan kelompok yang efektif dan dapat dijadikan sebagai teknik dalam layanan bimbingan kelompok harus memenuhi ciri-ciri sebagai berikut :
a. Sederhana
b. Menggembirakan
c. Menimbulkan suasana santai dan tidak melelahkan
d. Meningkatkan keakraban
e. Diikuti oleh semua anggota kelompok

\section{Bimbingan Kelompok Model Permainan}

Bimbingan kelompok model permainan adalah suatu kegiatan bimbingan yang diberikan kepada sekelompok individu atau anak untuk membantu menyelesaikan masalah baik itu masalah pendidikan atau pengajaran, pekerjaan, situasi sosial, dan sebagainya dengan menggunakan permainan yang berguna untuk merangsang dan membina pengalaman-pengalaman pribadi dan sebagai kelompok.

Permainan dilakukan dalam suasana yang rileks dan menyenangkan, sehingga peserta akan mendapatkan suatu pengalaman. Kemudian mereka diajak untuk menghayati pengalaman tersebut kemudian mendiskusikannya sehingga mereka menyadari perasaan dan reaksi-reaksi fisik mereka. Setelah itu, mereka diajak untuk 
mengungkapkan hal-hal yang dialami waktu latihan atau permainan berlangsung. Pengalaman yang diperoleh kemudian diolah kelompok bersama pembimbing, dengan cara mendiskusikannya dan menarik kesimpulan.

Prosedur pelaksanaan secara umum :

- Tahap permulaan

Fasilitator mengusulkan suatu permainan/ latihan, menjelaskan cara permain serta peraturan permainan. Ia harus memastikan bahwa setiap peserta sudah mengerti permainan yang akan dijalani.

- Tahap bermain

Fasilitator tidak ikut berperan. Hasil dari permainan/ latihan yang sedang dijalankan merupakan tanggung jawab kelompok dan masingmasing anggota kelompok. Merekalah yang menentukan proses bermain. Fasilitator mengamati proses bermain supaya dapat dibahas bersama kelompok setelah permainan berakhir.

- Tahap evaluasi

Tahap ini sangat penting dan tidak boleh dilewatkan begitu saja. Setelah permainan selesai dan dievaluasi, arti dan makna dari permainan/ latihan yang baru dilakukan akan jelas bagi peserta.

Fasilitator mendorong para peserta untuk memikirkan pengalamanpengalaman mereka yang baru dan memberanikan mereka untuk mengungkapkan perasaannya. Akhirnya, fasilitator dapat menyimpulkan dan menunjukkan hasil ataupun dasar yang penting dari latihan yang telah dilakukan. 
Teknik permainan yang digunakan antara lain :

a. Permainan Balok Susun

Tata cara permainan :

1. Posisi duduk peserta dibuat dalam bentuk lingkaran

2. Pemandu meminta anak untuk membentuk bentuk benda dengan mengambil balok dengan jumlah yang dibatasi, dengan jumlah balok yang dibatasi diminta untuk membentuk kreasi yang dia mintai

b. Bermain api

Tata cara permainan :

1. Peserta dibagi menjadi kelompok yang kecil, berbaris berderet dan menjaga jarak kurang lebih 3 meter setiap orangnya

2. Setiap peserta diberi satu biji korek api

3. Nyala api dimulai dari pemandu.

4. Api orang pertama diberikan kepada orang kedua dengan cara mendekat kepada orang kedua yang sudah siap memegng biji korek api sendiri.

5. Demikian seterusnya

6. Orang terakhir harus berjalan menuju lilin di epan untuk dinyalakan. Peserta yang lebih dulu menyalakan lilin, berarti kelompok tersebut menjadi pemenang

c. Bermain kertas berwarna

Tata cara permainan : 
Peserta diberikan sejumlah kertas, kemudian meminta anak untuk membuat kreatifitas sesuai dengan keinginannya

d. Gambar berlanjut

Tata cara permainan :

1. Peserta dibagi menjadi kelompok yang kecil, berdiri berderet dengan posisi masing-masing peserta menghadap ke depan

2. Pemandu membagikan spidol kepada setiap peserta kelompok dan satu lembar kertas manila kepada setiap kelompok

3. Permainan diawali dari orang yang berdiri paling belakang. Orang ini membuat goresan/ garis maksimal 2 sekehendak hatinya

4. Kertas lalu diberikan kepada orang kedua yang ada didepannya yang kemudian melanjutkan dengan maksimal dua garis juga

5. demikian seterusnya hingga orang terakhir yang berdiri paling depan. Pemenangnya adalah mereka yang paling cepat selesai namun bentuk gambarnya jelas

e. Lipat melipat bersama

Tata cara permainan :

1. Peserta dibagi menjadi kelompok yang kecil, membentuk barisan berderet

2. Orang pertama dari setiap kelompok mendapatkan selembar kertas sebagai bahan yang akan dilipat 
3. Ketika pemandu memberi aba-aba mulai, peserta pertama baru diperbolehkan melipat. Masing-masing peserta hanya diperbolehkan maksimal 2 lipatan

4. Kertas lipatan diberikan kepada orang berikutnya, kemudian dilanjutkan lipatannya

5. Permaian berlanjut sampai orang terakhir. Pemenangnya apabila kelompok mampu menyelesaiak pekerjaannya denga cepat dan hasil lipatan terlihat bentuknya

f. Pesan gambar berantai

Tata cara permainan :

1. Peserta dibagi menjadi kelompok yang kecil, berbaris berderet memanjang. Boleh berdiri atau duduk

2. Setiap peserta mendapatkan kertas dan alat tulis. Orang pertama dalam setiap kelompok membuat seluruh lukisan apa saja menurut gagasannya

3. Apabila lukisan tersebut selesai, kemudian ditunjukkan kepada anggota kelompok dengan batasan waktu yang sangat singkat dan hanya ditunjukkan sekali

4. Peserta kedua mengulang gambar yang sama yang dilihatnya

5. Demikian seterusnya hingga orang terakhir

6. Pemenangnya adalah kelompok yang dapat melakukan hal tersebut dengan cepat dan tepat

\section{METODE PENELITIAN}


Penelitian ini termasuk penelitian kuantitatif dan menggunakan pendekatan eksperimen yaitu penelitian yang dimasudkan untuk mengetahui ada tidaknya akibat atau pengaruh dari sesuatu yang dikenakan pada subyek penelitian.

Dalam penelitian ini menggunakan rancangan penelitian preksperimental design dengan model pretest-post test one group design, yaitu eksperimen yang dilakukan pada satu kelompok saja tanpa kelompok pembanding. Dengan tujuan untuk mengetahui perbedaan skor kemampuan penyesuaian diri di sekolah dengan menggunakan layanan bimbingan kelompok, dengan mengukur tingkat penyesuaian diri siswa di sekolah sebelum perlakuan (pre-test) dan setelah diberi perlakuan dalam jangka waktu tertentu (post-test).

Gambar I

Pre-test and Post-test One Group Design

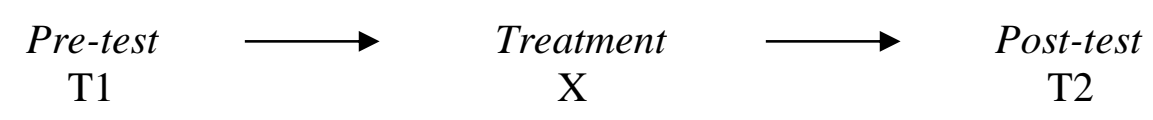

Keterangan :

T1 : Tes Awal (Pre-Test) sebelum pemberian perlakuan

$\mathrm{X} \quad$ : Treatment (perlakuan) disini adalah pemberian bimbingan kelompok model permainan belajar bersikap

T2 : Tes Akhir (Post-Test) setelah pemberian perlakuan

a. Prosedur Penelitian

1. Pre test 
Menentukan siswa yang mempunyai tingkat kemampuan penyesuaian diri yang rendah menggunakan angket yang sudah diuji validitas dan reliabilitas. Angket diberikan pada anak kelompok TK A. Maksud pemberian pre test adalah untuk mengetahui siswa yang memiliki tingkat kemampuan penyesuaian diri yang rendah (menemukan subyek penelitian). Setelah angket diberikan dilakukan penghitungan skor yang telah ditentukan.

\section{Perlakuan}

Setelah diketahui siswa yang memiliki tingkat penyesuaian diri yang rendah, maka diberikan perlakuan bimbingan kelompok model permainan belajar bersikap. Adapun permainan yang diberikan adalah:
a. Permainan Balok Susun
b. Bermain api
c. Bermain kertas berwarna
d. Gambar berlanjut
e. Lipat melipat bersama
f. Pesan gambar berantai

\section{Post test}

Melakukan post test dengan disebarkannya kembali angket untuk mengukur kemampuan penyesuaian diri di sekolah setelah diberikan perlakuan bimbingan kelompok model permainan belajar bersikap. 
2. Tahap Analisis Data

Analisi data yang dipakai Adalah Analisis Statistik dengan menggunakan Uji Jenjang Wilcoxcon

3. Tahap Pembahasan

Tahap ini berisi tentang pembahasan hal-hal yang dianggap penting dalam penelitian

4. Sekala Pencapaiana Anak

Skala Capaian Perkembangan Anak, di turunkan dari rencana pelaksanaan harian (RPPH) yang di antaranya terdapat beberapa indikator yang sebelumnya sudah tercantum di dalam RPPH. Penilaian yang di gunakan oleh guru harus menggunakan penilaian dengan skala yang di tetapkan seperti :

$\mathrm{BB}=$ Belum Berkembang

MB = Mulai Berkembang

$\mathrm{BSH}=$ Berkembang Sesuai Harapan

$\mathrm{BSB}=$ Berkembang Sangat Baik

Dalam penelitian ini menggunakan angket yang disusun berdasarkan kisikisi variabel penelitian. Adapun kisi-kisi dari variabel penelitian dapat dilihat pada table dibawah ini;

Tabel 3.1

Kisi-kisi Angket Kemampuan

Penyesuaian Diri Di Sekolah

\begin{tabular}{|c|c|}
\hline $\begin{array}{l}\text { Jumlah } \\
\text { Bintang }\end{array}$ & Skala \\
\hline
\end{tabular}




\begin{tabular}{|l|l|}
\hline & $\begin{array}{l}\text { Capaian Perkembangan } \\
\text { Kreatifitas Anak Melalui } \\
\text { Metode Bermain Peran }\end{array}$ \\
\hline
\end{tabular} $\begin{aligned} & \begin{array}{l}\text { BB = Anak belum mampu } \\
\text { memahami penjelasan guru } \\
\text { tentang kegiatan bermain peran. }\end{array} \\
& \begin{array}{l}\text { MB = Anak mampu memahami } \\
\text { penjelasan guru tentang kegiatan } \\
\text { bermain peran dengan bantuan } \\
\text { guru. }\end{array}\end{aligned}$

Dalam penelitian ini metode analisis data yang digunakan adalah analisis statistik. Hal ini disebabkan data yang dikumpulkan berupa angka atau bilangan (penelitian kuantitatif). Karena data yang disajikan berbentuk ordinal dan berdistribusi normal yang artinya subyek dalam penelitian ini kurang dari 25, yaitu terdapat 14 subyek $(\mathrm{N}=14)$ yang akan mendapatkan perlakuan. Maka dalam penelitian ini digunakan teknik analisis data statistik non parametrik. Menurut Siegel "Jika sampelnya kecil, hanya tes non parametrik yang bisa digunakan".

Teknik analisis non parametrik yang digunakan untuk menguji hipotesis dalam penelitian ini adalah uji Jenjang Wilcoxon yang merupakan penyempurnaan dari uji tanda (Sign test). Hal ini disebabkan penelitian ini sampel-sampelnya saling berkorelasi dan datanya berbentuk ordinal (data yang berupa peringkat atau ranking yaitu rendah dan tinggi). Menurut Martini Uji Jenjang Wilcoxon ini digunakan untuk menguji hipotesis komparatif dua sampel yang berkorelasi bila datanya berbentuk ordinal (berjenjang). Dalam Uji Jenjang Wilcoxon, bukan saja tanda (positif negatif) besarnya beda atau selisih(X-Y) juga diperhatikan . 
Adapun prosedur Uji Jenjang Wilcoxon adalah sebagai berikut :

1. Berikan jenjang (rank) untuk tiap-tiap beda dari pasangan pengamatan (XiYi) sesuai dengan besarnya dari yang terkecil sampai terbesar tanpa memperhatikan tanda dari beda itu (Nilai beda absolute). Bila ada dua atau lebih yang sama, maka jenjang untuk tiap-tiap beda itu adalah jenjang rata-rata.

2. Bubuhkan tanda positif atau negatife pada jenjang untuk tiap-tiap beda sesuai dengan tanda dari beda itu. Beda O tidak diperhatikan .

3. Jumlahkan semua jenjang bertanda positif atau semua jenjang yang bertanda negatif tergantung dari mana yang memberikan jumlah yang lebih kecil setelah tandanya dihilangkan. Notasikan jumlah jenjang yang lebih kecil ini degnan $\mathrm{T}$

4. Bandingkan nilai $\mathrm{T}$ yang diperoleh dengan nilai $\mathrm{T}$ untuk uji jenjang beda wilcoxon

Jumlah T inilah yang dipakai untuk menguji hipotesis.

Ho : Tidak ada perbedaan pengaruh perlakuan

Ha : Terdapat perbedaan pengaruh perlakuan

\section{HASIL DAN PEMBAHASAN}

Berdasarkan hasil Pre test diperoleh hasil terdapat 8 siswa yang memiliki kreatifitas rendah berdasarkan kategori yang telah dibuat, dari sini peneliti memberikan perlakuan bimbingan kelompok model permainan dengan kegiatan sebagai berikut:

Berikut ini disajikan kegiatan perlakuan bimbingan kelompok model permainan belajar bersikap yang digunakan untuk meningkatkan kemampuan penyesuaian diri di sekolah pada 8 siswa yang berada pada kategori rendah. 

a. Permainan Balok Susun
b. Bermain api
c. Bermain kertas berwarna
d. Gambar berlanjut
e. Lipat melipat bersama
f. Pesan gambar berantai

Setelah diberikan perlakuan seperti bimbingan kelompok model permainan, maka peneliti melakukan kegiatan post test pada ke 14 siswa tersebut yang mendapat perlakuan, guna mengetahui bagaimana hasil pemberian perlakuan terhadap siswa.

Dari hasil post test yang dilakukan diperoleh data yang berbeda dengan kegiatan pre test. Ini tergambar sari table dan histogram berikut:

Tabel 4.4

Histogram pretest-postest kreatifitas anak 


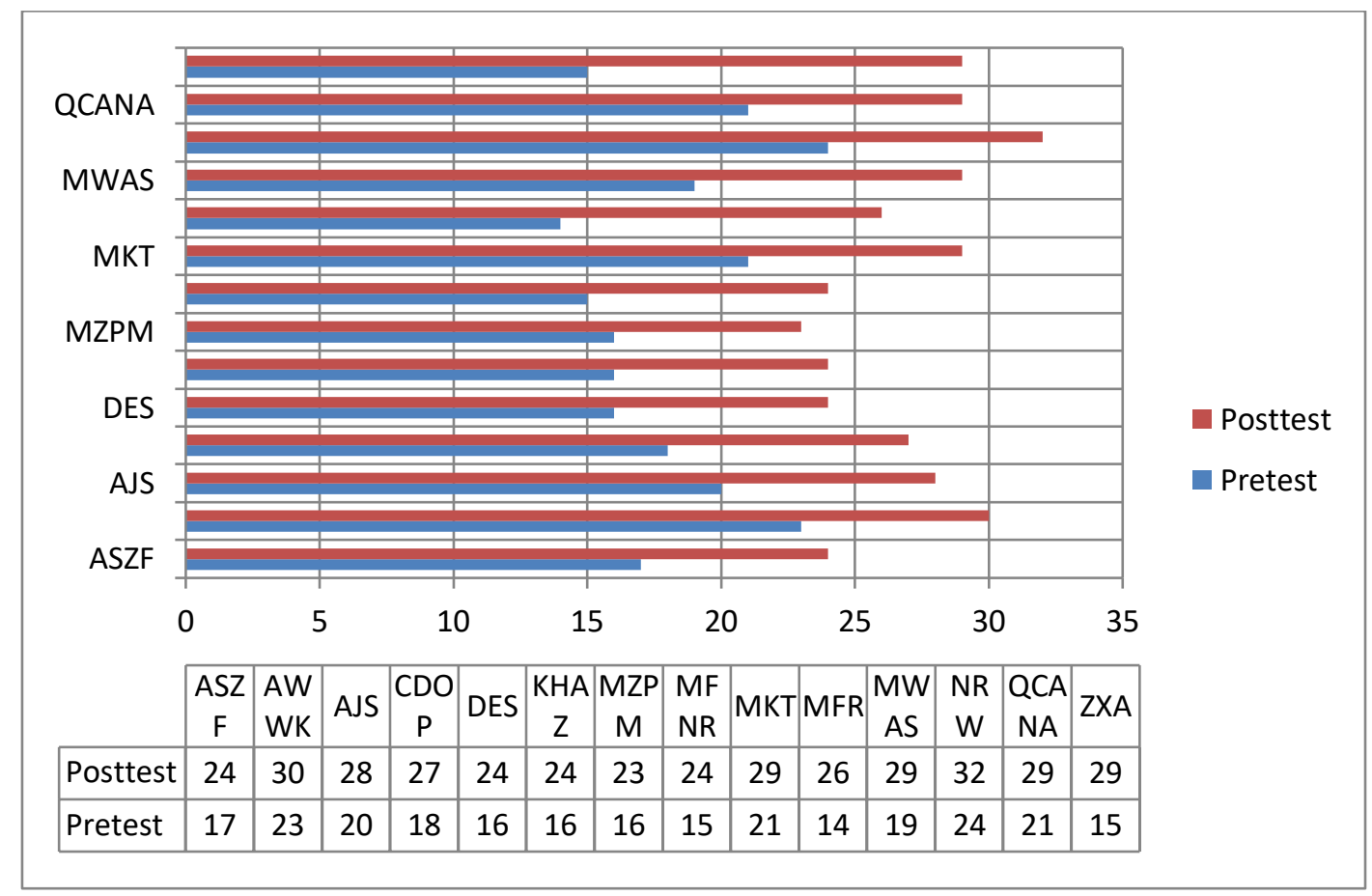

Berdasarkan hasil analisi di atas menunjukkan bahwa penelitian bimbingan kelompok model permainan dapat digunakan untuk meningkatkan kreatifitas anak. Ini berarti bahwa ada perbedaan yang positif mengenai kreatifitas anak, yaitu semakin meningkatnya kreatifitas anak setelah perlakuan bimbingan kelompok model permainan.

\section{PENUTUP}

Berdasarkan penjelasan yang telah disampaikan sebelumnya, maka dapat diambil kesimpulan bahwa: hasil analisis data pre test dan post test menggunakan uji jenjang Wilxocson, diketahui bahwa nomor urut yang bertanda negatif $=$ " 0 " sedangkan jumlah nomor urut yang bertanda positif $=36$, dengan demikian nomor urut dengan jumlah terkecil atau $\mathrm{T}=0$. Berdasarkan tabel nilai kritis $\mathrm{T}$ untuk uji jenjang Wilcoxon dengan taraf signifikan $5 \%$ dan $\mathrm{N}=14$ diperoleh $\mathrm{T}_{\text {tabel }}=4$ sehingga $\mathrm{T}_{\text {hitung }}$ lebih kecil $\mathrm{T}_{\text {tabel }}(0<0.05$ berarti Ho ditolak dan Ha diterima, maka hipotesis yang 
diajukan dapat diterima yaitu terdapat perbedaan yang signifikan pada skor kreatifitas anak di kelompok A sebelum dan sesudah penerapan bimbingan kelompok model permainan Darrul Ma’arif, Payaman, Lamongan.

\section{REFERENSI}

Elfiah, Rifda. Bimbingan dan Konseling Anak Usia Dini. 2017. Depok. Raja Grafindo Persada.

Panuju, Panut dan Ida Umami. 2005. Psikologi Remaja. Yogyakarta: Tiara Wacana Sunarto dan Hartono Agung. 1999. Perkembangan Peserta Didik. Jakarta: Rieneka Cipta.

Tohirin. 2007. Bimbingan Dan Konseling Di Sekolah Dan Madrasah (Berbasis Integrasi). Jakarta: Raja Grafindo Persada

Willis, Sofyan. 2005. Remaja Dan Masalahnya. Bandung: Alfabeta.

Willis, Sofyan. 1994. Problem Remaja Dan Pemecahannya. Bandung: Angkasa.

Rumini, Sri dan Sundari Siti. 2004. Prekembangan Anak Dan Remaja. Jakarta: Rineka Cipta.

Nurihsan, Achmad Juntika. 2006. Bimbingan Dan Konseling Dalam Berbagai Latat Kehidupan. Bandung: Refika Aditama.

Nursalim, Mochamad dan Suradi. 2002. Layanan Bimbingna Dan Konseling. Surabaya: UNESA University Press.

Martini. 2005. "Prosedur dan Prinsip-prinsip Statistika". Surabaya,Unesa University press

Siegel, Sidney. 1990. Statistik Non Parametrik Untuk Ilmu Sosial. Jakarta: Gramedia Pustaka Utama. 